\title{
CRISIS OF MEANING IN CONNECTION WITH MENTAL DISTRESS OF A MODERN MAN
}

\section{KRIZA SMISLA U VEZI S MENTALINM TEGOBAMA MODERNOG ČOVJEKA}

\author{
Sebastjan Kristovič \\ Alma Mater Europaea, European Centre Maribor, Maribor, Slovenia \\ Alma Mater Europaea, Europski center Maribor, Maribor, Slovenija
}

\section{Abstract}

In contrast with the contemporary spirit, which directs a person towards their own needs, satisfactions, and desires, logotherapy views the person and its life as an assignment. Man is not an individual "for himself" (according to Freud, the main internal motivational force is "the will of pleasure" and "the will of power" according to Adler), but a being of sense or a being for someone or something. According to Frankl, the purpose is defined as tasks, which life sets us in a precise moment and in a precise situation. These are tasks requiring a responsible reaction and a specific realisation of values. Each of them is unique. Each individual is responsible for a task, and only he can respond to it in a responsible manner. In this sense, life can be seen as a chain, whose links are the tasks themselves. Each individual is unique, with a unique goal in life, which consists of individual, equally unique tasks. The centre of logotherapy is future - tasks and meanings. The founder of logotherapy is Viktor E. Frankl, who was a doctor of medicine and doctor of philosophy, and a professor of neurology and psychiatry at the University of Vienna. The third psychotherapeutic school in Vienna - logotherapy - is based on a holistic approach to an individual, which means that it analyses a person on a physical, mental, and spiritual level. Spiritual dimension is, among others, a place of realisation of responsibility and freedom or space of realisation of actual possibilities and tasks. Existential
Sažetak

Za razliku od suvremenog duha, koji usmjerava osobu prema vlastitim potrebama, zadovoljenjima i željama. Logoterapija promatra osobu i njezin život kao zadatak. Čovjek nije pojedinac "za sebe" (prema Freudu, glavna unutarnja motivacijska snaga je "volja zadovoljstva" i "volja moći" prema Adleru), već biće smisla ili biće za nekoga ili nešto. Prema Franklu, svrha je definirana kao zadaci koje nam život postavlja u točan trenutak i u preciznoj situaciji. To su zadaci koji zahtijevaju odgovornu reakciju i specifično ostvarenje vrijednosti. Svaki od njih je jedinstven. Svaki pojedinac odgovoran je za zadatak i samo on može na njega odgovoriti na odgovoran način. U tom smislu, život se može promatrati kao lanac, čije su karike sami zadaci. Svaki pojedinac je jedinstven, s jedinstvenim ciljem u životu, koji se sastoji od pojedinačnih, podjednako jedinstvenih zadataka. Središte logoterapije je budućnost - zadaci i značenja. Utemeljitelj logoterapije je Viktor E. Frankl, koji je bio doktor medicine i doktor filozofije, te profesor neurologije i psihijatrije na Sveučilištu u Beču. Treća psihoterapeutska škola u Beču - logoterapija - temelji se na holističkom pristupu pojedincu, što znači da analizira osobu na fizičkoj, mentalnoj i duhovnoj razini. Duhovna dimenzija je, između ostalog, mjesto realizacije odgovornosti i slobode ili prostor ostvarenja stvarnih mogućnosti i zadataka. Egzistencijalna kriza, egzistencijalni vakuum i noogene neuroze pitanja su i mentalni problemi koji 
crisis, existential vacuum, and noogenic neuroses are issues and mental problems, which originate from the spiritual dimension. This means failing to perceive and failing in life as an assignment. The empirical part of the research, which is based on the psychometric instrument LOGO-test, performed on two hundred respondents, gave us the results that even 24 percent of respondents are in various mental distresses and seriously existentially endangered. The paper highlights the most problematic areas and causes for such mental distress. The COVID-19 pandemic only deepened and revealed this crisis of meaning.

\section{Introduction}

The spirit of time dictates people with consuming values (parvenuism, desire for quickly achievable goals, fighting for money, prestige, pleasure, power, authority, egoism, and subjectivism). The question that occurs is, "How do we resist this?" Must an individual really experience a hard moment in life to change his system of values? Could he live differently if he had loving parents, suitable education, teachers, better environment, etc.? The spirit of time directs an individual to focus on himself or to set himself as the epicentre of the world while, from the logotherapeutic point of view, the real essence of human engagement in life is completely elsewhere - in overcoming oneself in striving to the meaning and achieving life with a meaning.

Basic human striving or desire is the desire for happiness and inner satisfaction. Most of all, people desire to be happy. But a dangerous trap occurs here, that 'fatal' crossroads where the new-age people miss direction so often. The more an individual seeks comfort, pleasure and happiness and uses all his powers to achieve these, the more he distances himself from it. A chase starts and it can sometimes be tragic. This is the so-called 'happiness paradox' /1/; the more the person tries to be happy or to enjoy and consequently achieve the state of happiness, pleasure, homoeostasis, the more it evades him. A threatening pit of human existence opens, the dichotomy between being and having (must have). Consequently, the person essentially unhappy even frustrated in the relationship with himself and the world. The main ISSN 1330-0067 potječu iz duhovne dimenzije. To znači ne shvatiti i propasti u životu kao zadatak. Empirijski dio istraživanja, koji se temelji na LOGO-testu psihometrijskom instrumentu, provedenom na dvjesto ispitanika, dao nam je rezultate da je čak 24 posto ispitanika u različitim psihičkim tegobama i ozbiljno egzistencijalno ugroženo. Rad ističe najproblematičnija područja i uzroke takvih psihičkih tegoba. Pandemija COVID-19 samo je produbila i otkrila ovu krizu smisla.

source of frustration comes with the question, "Who am I and who could I or should I be, who should I become?" Is the path of utilitarianism, hedonism and conformism, which are the main labels of the spirit of time, the path towards personal integration, existential security, and human 'perfection'? Or is it a side path which leads to existential disorientation, loss of meaning, and existential vacuum?

Such attitude mostly originates from a professional or anthropological delusion of understanding of a person. The very beginning can be seen in the occurrence of rationalism, which started to spread with Descarter and reached its peak with Hegl (real is rational, and rational is real); the ideal is to know, understand, control, and to achieve an absolute autonomy. Moreover, rationalism set up the foundation to empirical and separation science, which lost the perspective of a human being as a whole (holistic approach) and started to treat him differentially, sometimes even disparately. Freud, who has marked the entire field of psychology, psychotherapy, and psychiatry to date, labelled humans as beings of pleasure ('the will for pleasure'; the principle of homoeostasis). According to Adler, a person is a being of power ('will to power'). This means that conception of a human is the centre of a problem. Frankl stated that Paul Schilder labelled psychoanalysis as Weltanschauung (the world view). He said that, "It cannot be about the question whether psychotherapy is based on a world view or not, but of the world view, which is its basis, is right or wrong" /2/. Frankl sets humanity as the criterion whether the determined anthropological orientation is right or not. It is right only if it

Coden: IORME7 
preserves human humanness. Humanness is kept by those that understand it in its entire vastness and complexity. Therefore, many antinomies and differences occur in human sciences, usually without the need for it - and always at the cost of a human being. This is the so-called humanist fundamentalism, which depersonalises the human. Frankl perceived this as decisive moments of the new-age nihilism. "Nihilism is not uncovered by talking about Nothing, but it hides behind the cover of expression 'nothing more than' «/3/. Frankl stated that, "Today we live in a time of specialists, and they give was only partial perspectives and images of reality. Due to trees of research achievements, the researcher no longer sees the forest of reality «/3/. He determines that reductionism has become the cover for nihilism. The notion terrible simplificateurs has been known to us for quite some time, and Frankl warned about a 'new' danger - terrible généralisateurs /4/. Gordon W. Allport uses Freud's position on faith to illustrate, "To him, religion is basically neurosis in the individual, a form for personal escape. Father's image is in the root of the thing. Therefore, we cannot take a religious emotion at face value when it exists in some personality" /5/. Moreover, we are actually degrading his dignity. It is the dimension of dignity, which is the constituent element of human /6/. Frankl warned us that, on a basis of such 'professional' dispositions of a human, we degrade the human. Since its meaning and values are no longer taken seriously, we do not take him seriously as a person. Consequently, 'dehumanisation' or reduction, simplification and determinism occur. In other words, there is a danger of alienation or the gradual decomposition/degradation of dignity. Realized dignity is manifested in the human attitude towards himself and to the other or in the self-respect and respect of the other $/ 7 /$. To Freud, philosophy was also one of the, "Most decent forms of sublimation of repressed sexuality" /8/. If this was true, it would mean that philosophy is theoretisation or even theologisation of hidden neurosis, which does not hold any serious professional critic. Frankl asked himself, "The question whether it is not the other way round and that neurosis is not the exact consequence of a mistaken philosophy, is not considered." /8/ ISSN 1330-0067
Charlotte Bühler states that, "According to Freud's principle of homoeostasis, the highest meaning is to achieve that type of complete satisfaction which would restore the individual's balance by calming down all of his desires. From this aspect, all cultural creations of humanity actually become side products of the drive for personal satisfaction /9/.

A human himself and his personal satisfaction are in the centre of a personal strivings. Self-realisation is all about striving of a person to realise himself in all possible and potential directions and dimensions. However, tendency towards homoeostasis can be explained with a strive for the smallest external and internal tension. It means the elimination all factors that cause this tension. On the other side, life situations, which cause this tension or could potentially cause it, should be avoided. Such orientation shuts down a person into himself, and 'isolates' a human being from the real world and life. It is therefore not unusual that Kurt Goldstein came to conclusions (field of neurology and psychiatry) that this is actually a pathological principle. The person is not oriented towards the world, life, tasks, towards others, but is oriented into himself. This way he creates a barrier and distance from realisation of meaning and values, which life puts in front of him. According to this theory, homoeostatic satisfaction is the purpose of all strivings. Therefore, everything else is of a secondary meaning or is working for this meaning, which means health and the highest possible fulfilment of human life. The moment of pleasure is in the background of these theories; the pleasure of fulfilling, the drives and satisfying the needs. Frankl claimed that the principle of pleasure means bare modification in the fact that it serves to a higher principle - the homoeostatic one. "As psychoanalysis pushed the will to pleasure in the forefront as a principle of pleasure, individual psychology emphasised the will to power in the form of the so-called striving to validation. But Adler's striving for validation is no longer about pushing a person to something which might be put aside aggression from sexuality, which Freud moved in the forefront, but it is about an active centre (Scheler) of will that comes from a person" /10/. Considering the 
'happiness paradox', it is evident that Freud's principle of pleasure is a great lapse. The principle of pleasure has to be considered as a homoeostatic principle. Frankl warned us from general striving of the world and de-humanised psychology: "The whole world has only one meaning in its heart; we must get rid of aggressive potentials, suffering, and responsibility. This is not a person. The person is there where their actions are sensible. The person is there where they love someone. The person does not want to react as psycho-dynamics teach us, they do not want do change the causes as taught by behaviourism. The person wants to act in the world, full of possibilities, sense, and potentials" /11/.

\section{Life as an assignment}

One of the fundamental problems of a modern person, despite that human life is not threatened, is in the feeling of senselessness and internal void, which is a paradox of its own kind. Modern person needs the feeling of reasonableness more than he needs money. This has been confirmed by numerous scientific researches, such as: "Irvin Yalom from the Stanford university determined that randomly selected sample between the patients of psychotherapy confirmed that $30 \%$ of them sees no meaning in their lives, and that this is also how they live. This is spicy since I read one week after this in an Austrian article statistic where 29 $\%$ of people, which is one per cent less, responded that life has no more meaning for them. We ask ourselves, where does this come from? People have their heads filled with this question; why live if they do not know what would be worth living for" /11/. Frankl mentioned Goethe, who wrote a book using his last strengths, and had died two months after it was published. He also mentioned a famous professor and researcher of schizophrenia, Bertse, who was maximally engaged in its profession at the age of 91, his desk was still full of books. Then Frankl set the question about the senseless life of retired people, "Is this a disease or just suffering?" /11/. The answer is clear; it is not a disease. To find some meaning in life, it is always essential that a person has a goal. Freud's 'striving for pleasure' is explained by logotherapy as compensation for frustrated striving for ISSN 1330-0067 sense. Adler's 'striving for power' is the means for searching the meaning. Logotherapy /12/ deals with the meaning of human existence, and with searching of this meaning. The meaning is defined as tasks which life sets us in a precise moment and in precise situations. Basic assumptions for searching meaning are human freedom and responsibility. Each individual has many options available in every moment, but he must recognise the most appropriate one, which has the greatest importance according to his own values., The individual decides which option to select with the power of free will. From the phenomenological point of view, freedom is a gift and a burden at the same time. It enables the individual to create his own existence, and requires constant decisions from the person at the same time, and consequently also requires acceptation of responsibility for his actions and life. In personal decisions, each person is free in his essence, which means that he is responsible for his actions and decisions consequences are personal credits or guilt. Uniqueness and specificity of meaning lies in the search of life assignments, which life sets in front of each individual. If the meaning, which is always and, in every case, conditioned with a certain situation and moment, is not fulfilled it can result in an existential frustration or a crisis of meaning. Consequence of an existential crises is a frustrated will for meaning; only then the will for pleasure, comfort, power, etc. which increasingly affect human activities, come the forefront. These motivations are actually a deviation from normal motivational orientation, which is the will for meaning. The above can be explained as a pathological or neurotic motivation in human operation.

One of the main three pillars of logotherapy is 'the will to meaning', which is actually an antipode to 'will to power' (Adler) and to 'will to pleasure' (Freud). A person's main driving force is the desire or the effort to find the meaning. Each individual has a grown-in need for meaning, which has been labelled by Frankl as 'the will to meaning'. From the logotherapeutic point of view, human is a physical, mental, and spiritual being. Human is not actually composed of physical, mental, and spiritual dimensions, but human is all of that. It means that one dimension cannot be separated from the other 
two and treated independently. Human is actually constituted from a whole of all three dimensions which cannot be separated. Human sciences consider and treat human mostly as a psycho-physical being and reduce him to a collection of biological and psychic mechanisms. They either disregard the spiritual dimension or include a simplified and reductionist consideration of a conglomerate of spiritual and mental spheres, which are, next to the physical dimension, perceived as the other (integral) part of a human being. It is interesting that the spiritual dimension is what separates human from other animals; and modern science often forgets this dimension. Frankl brought some king of re-humanisation of human sciences. Spiritual dimension is responsible for correct understanding of a person and his personality. Spiritual dimension is the 'pool' of inner strength from which human take the power to rise above strivings, pushes, and other 'forces' that determinate human and consequently make him non-free and non-responsible. Spiritual dimension is after all a 'place' where freedom, creativity, responsibility, ideals, intuition, 'will to meaning' become real, and where personal decision of a person is more important than determination or conditioning.

It follows that human is not the one asking for meaning, it is the other way round; he is the one being asked, "Human must answer questions asked by life by himself; but these answers are always in the form of actions. Only by acting, it is really possible to answer 'life questions' - and the answer to them is answering to our being. That being is 'ours' only if we are responsible for it" $/ \mathbf{1 3} /$. The meaning and the purpose of life lies in answering responsibly. The highest level of self-awareness is the awareness of an individual that he is constantly being asked and called to respond. At this stage, logotherapy opens another horizon of understanding of responsibility. Classic definition of responsibility is that human is responsible for consequences of his actions. Logotherapy understands responsibility as a wider concept (not as retrospectively and introspectively), we are not just responsible for the actions we have done, but also for the actions which we must or should have done. Considering that ISSN 1330-0067 responsibility is a problematic term these days, it is also reduced only to the past. Abandonment of tasks and actions also belong to responsibility. We can understand life as an assignment whose fulfilment is our responsibility.

A human being always has some kind of a task to perform or respond to. Moreover, life itself is a task. And this task is not directed towards self-realisation, but towards overcoming oneself, towards something that is outside the human himself. A human actually realises himself the most when he 'forgets' about himself, when he does not see only himself and his interests in front of him. Logotherapy directs human towards a more authentic and meaningful life, which is present in activity and dynamics, and not in a passive state of 'inner peace' and striving towards homoeostasis. Goethe's words, mentioned by Frankl, say a lot, "How can we learn about ourselves? Never by watching, but by acting. Try to do your duty, and you will instantly learn about yourself. And what is your duty? The task of that day" /14/. If simplified, we could even say that tasks are our meanings. If we do not fulfil a task, if we respond to a task which life has given us in a specific moment and situation irresponsibly, we do not fulfil the meaning. Logical conclusion arises from this; the more meaningful answers in the life of an individual, the more meaningful, full, and existentially 'safe' his life will be; and in contrast, the more senseless decisions, missed moments and goals, the more life itself becomes 'senseless', empty, banal, shallow, and consequently the individual starts sliding in the state of existential crisis and existential vacuum.

\section{Method}

In the theoretical part we used the inductivedeductive method, the compilation method, the descriptive method, the comparative method and the analytical-synthetic method. The empirical part focuses on a quantitative statistical approach and a standardised / validated measuring instrument, the LOGO test. We processed the results of the empirical part of the research with the SPSS statistical software. 


\section{Purpose and goals of the research}

The main purpose of the research was to identify, differentiate and evaluate noogenic issues, the crisis of meaning and to find parallels / correlations between the loss of meaning and the neuroses of modern times. It is about identifying the most acute areas of life and establishing how many respondents experience their lives as meaningful and satisfying.

The basic research question is: What are the main areas in an individual's life that have the greatest impact on the crisis of meaning?

Related to the main research question, we set ourselves two more hypotheses:

$\mathrm{H} 1$ : At least twenty percent of respondents experience a crisis of meaning.
H2: The root cause of the existential crisis and the existential vacuum is in not perceiving and not realising one's own life as a task.

\section{Respondents}

Representative sample included 200 female respondents, aged 20-60. Average age of respondents was 38.73 years. Respondents were randomly selected as part of a variety of professional training for parents, teachers, and professional teams (seminars, school for parents, lectures, etc.) across Slovenia. They were people with a higher or university education. The measuring instrument was personally presented and distributed to the respondents. They also received instructions. Due to this personal approach, the rate of received tests was $100 \%$.

\begin{tabular}{|c|c|c|}
\hline Age (years) & No. of respondents & Percentages (\%) \\
\hline $16-29$ & 41 & 20.5 \\
\hline $30-39$ & 66 & 33 \\
\hline $40-49$ & 66 & 33 \\
\hline $50-60$ & 27 & 13.5 \\
\hline
\end{tabular}

Table 1: Age range of respondents

\section{Measuring instruments and procedures}

We used the internationally and professionally established measuring instrument (LOGO-test) for "measuring" meaning, existential frustration, and meaning orientation. The author of the LOGO-test is Elisabeth E. Lukas /15/ who has also standardised the test. She developed it within her doctoral dissertation at the Institute for Experimental and Applicable Psychology of the University of Vienna under the guidance of Giselher Guttman. The basic goal of the dissertation was to scientifically establish the validity of logotherapy by means of empirical evidence. It was to confirm the logotherapeutic axiom, which indicates a close correlation between mental health and the satisfactory fulfilment of inner meaning. The four basic characteristics of the LOGO test are:

1. It distinguishes between mentally healthy and mentally ill people and allows for reliable statements about their orientations towards meaning.

2. There is a greater dispersion of test results in mentally ill people than in mentally healthy people. This means that the ISSN 1330-0067 variational breadth of positive and negative approaches to the disease is large enough that, despite the disease, it also allows for a satisfactory "fulfilment of inner meaning".

3. Based on the test results, a cut-off point was determined which can be used to diagnose the intensity of possible noogenic problems.

4. Despite its heterogeneous sub-test, the test is one-dimensional and gender-homogeneous.

The LOGO-test /15/ is useful with respondents aged over 16 and measures the extent to which a specific person experiences meaning in life. It consists of three parts: The first part covers nine content categories which clearly represent the "meaningful factors" of human life: one's own well-being, self-realisation, family, main employment, sociability, interest, experience, service to belief and life hardship; while test part 2 attempts to psychometrically grasp the phenomenon of "existential frustration". This originates from the effects of frustration known to experimental psychology, which must be sought by experiencing Coden: IORME7 
meaning in its respective response if existential frustration is present. These are: aggression, regression, overcompensation, flight reaction, reasonable reconciliation, neurosis, and depression; while test part 3 consists of two parts. In addition to its "perspective value", the first part also fulfils the exemplification task for the second part. The existential essence of the three options is presented briefly and concisely, which the respondent must do in the second part of the third test part in accordance with his / her own life path.

\section{Results}

Results from the first part of the LOGO test show that, as the least important contents, respondents stated main employment (education, study, work, profession) (94), serving a belief (religion, politics, reform) (224) and life distress (overcoming illness, self-preservation, facing the facts) (268) which has a ratio of $1: 54$ compared to the most important contextual topic.

\begin{tabular}{|l|c|}
\hline Categorisation of nine content areas & Summation of responses \\
\hline $1 . \quad$ family & 5 \\
\hline $2 . \quad$ self-realisation & 13 \\
\hline $3 . \quad$ sociability & 16 \\
\hline $4 . \quad$ experience & 18 \\
\hline $5 . \quad$ interest & 65 \\
\hline $6 . \quad$ own well-being & 80 \\
\hline $7 . \quad$ main employment & 94 \\
\hline $8 . \quad$ serving a belief & 224 \\
\hline $9 . \quad$ life hardship & 268 \\
\hline
\end{tabular}

Table 2: Categorised content areas of the first part of the LOGO test

Spearman's correlation coefficient showed that serving a belief (0.667) and life distress (0.451) statistically affect the result most markedly.

\begin{tabular}{|c|c|l|l|l|l|}
\hline \multicolumn{2}{|c|}{ Everyone } & \multicolumn{2}{c|}{ Age group 16-29 years } & \multicolumn{2}{c|}{ Age group 30-39 years } \\
\hline family & 5 & self-realisation & 0 & family & 0 \\
\hline self-realisation & 13 & sociability & 3 & self-realisation & 4 \\
\hline sociability & 16 & family & 4 & sociability & 4 \\
\hline experience & 18 & experience & 7 & experience & 7 \\
\hline interest & 65 & main employment & 13 & own well-being & 18 \\
\hline own well-being & 80 & own well-being & 15 & interest & 23 \\
\hline main employment & 94 & interest & 16 & main employment & 43 \\
\hline serving a belief & 224 & serving a belief & 45 & serving a belief & 88 \\
\hline life hardship & 268 & life hardship & 58 & life hardship & 92 \\
\hline
\end{tabular}

Table 3: Content areas categorised by age group (Part 1) 


\begin{tabular}{|l|c|l|c|}
\hline \multicolumn{2}{|c|}{ Age group 40-49 years } & \multicolumn{2}{c|}{ Age group 50-59 years } \\
\hline family & 0 & sociability & 0 \\
\hline experience & 4 & experience & 0 \\
\hline self-realisation & 7 & family & 1 \\
\hline sociability & 9 & self-realisation & 2 \\
\hline interest & 19 & interest & 7 \\
\hline main employment & 30 & main employment & 8 \\
\hline own well-being & 34 & own well-being & 13 \\
\hline serving a belief & 71 & serving a belief & 20 \\
\hline life hardship & 90 & life hardship & 28 \\
\hline
\end{tabular}

Table 4: Content areas categorised by age group (Part 2)

The results show that age does not play an important role in categorising content areas. Respondents did not differ statistically significantly from each other. The difference is apparent in the first group (16-29 years), which put self-realisation in first place (acquisition of identity, appearance, success). "Replacement" can be explained by the fact that a person in the mentioned period is more self-oriented - in terms of building their existence, independence, identity, education, career, etc.

We were also interested in which items most influence the total value of the first part of the LOGO test. The following table shows the Spearman correlation calculation between the items of the first part of the LOGO test and the total sum of the whole first part (sum logo 1):

\begin{tabular}{|c|c|}
\hline $\begin{array}{l}\text { Categorised items of the second } \\
\text { part of the LOGO test }\end{array}$ & $\begin{array}{c}\text { Spearman's correlation coeffi- } \\
\text { cient sum logo 1 }\end{array}$ \\
\hline $\log 018$ & .667 \\
\hline $\log 019$ & .451 \\
\hline $\log 016$ & .447 \\
\hline $\log 014$ & .405 \\
\hline $\log 012$ & .298 \\
\hline $\log 011$ & .289 \\
\hline $\log 15$ & .241 \\
\hline $\log 013$ & .240 \\
\hline
\end{tabular}

Table 5: Correlation calculation for the first part according to Spearman 
As can be seen from Table 5 , the final result (statistically speaking) is most influenced by the items logo 18, logo 19 and logo 16.

In the second part of the LOGO-test, we have attempted to psychometrically assess the phenomenon of "existential frustration". This part of the LOGO test evaluates the frustrating effects in terms of the existential vacuum / sense crisis. Three of the highest ranked frustration effects are: aggression (144), regression (123), and over-compensation (115).

\begin{tabular}{|l|c|}
\hline Categorisation of the seven effects of frustration & Sum of answers \\
\hline 1. aggression & 144 \\
\hline 2. regression & 123 \\
\hline 3. overcompensation & 115 \\
\hline 4. flight reaction & 108 \\
\hline 5. reasonable reconciliation & 85 \\
\hline 6. neurosis & 76 \\
\hline 7. depression & 16 \\
\hline
\end{tabular}

Table 6: Psychometric evaluation of existential frustration

There are three possible answers to the claims: "Very often", "sometimes" and "never". Below are the results of individual responses for the three highest frustrating effects and which frustrating effects belong to a particular item. The items are intended as questions and ask the respondent if they have already experienced the following...:

The logo21 entry reads: "Feeling of helpless rage because you thought you had worked in vain until now." The accompanying effect of frustration measured by this item is aggression:

\begin{tabular}{|c|c|c|}
\hline Answers & No. of answers & Answers in \% \\
\hline never & 62 & 31.0 \\
\hline sometimes & 132 & 66.0 \\
\hline very often & 6 & 3.0 \\
\hline
\end{tabular}

Table 7: Basic display of answers logo21

The logo22 entry reads: "The desire to be a child again, to be able to start all over again." The accompanying effect of frustration measured by this item is regression:

\begin{tabular}{|c|c|c|}
\hline Answers & No. of answers & Answers in \% \\
\hline never & 127 & 63.5 \\
\hline sometimes & 70 & 35.0 \\
\hline very often & 3 & 1.5 \\
\hline
\end{tabular}

Table 8: Basic display of answers logo22

The logo23 entry reads: “The need to try to present life to yourself or to others more fully than it really is." The accompanying effect of frustration measured by this item is overcompensation: 


\begin{tabular}{|c|c|c|}
\hline Answers & No. of answers & Answers in \% \\
\hline never & 118 & 59.0 \\
\hline sometimes & 79 & 39.5 \\
\hline very often & 3 & 1.5 \\
\hline
\end{tabular}

Table 9: Basic display of answers $\log 023$

The correlation of age groups showed that in terms of the frustrating effects of depression there are no significant differences, except for the fourth age group. In the fourth age group (50-59), frustrating effects reasonable reconciliation and neurosis come first, while aggression is only third. It is also important to note that neurosis is also fairly present in the youngest age group (16-29).

In this part we are also interested in which items most influence the result of the second part of the LOGO test:

\begin{tabular}{|c|c|}
\hline $\begin{array}{l}\text { Categorised items of the second } \\
\text { part of the LOGO test }\end{array}$ & $\begin{array}{c}\text { Spearman's correlation coef- } \\
\text { ficient sum logo 2 }\end{array}$ \\
\hline $\log _{0} 21$ & .599 \\
\hline $\log 26$ & .598 \\
\hline $\log 023$ & .591 \\
\hline $\log 024$ & .472 \\
\hline $\log 22$ & .460 \\
\hline $\log 027$ & .356 \\
\hline $\log 025$ & -.108 \\
\hline
\end{tabular}

Table10: Correlation calculation for the second part according to Spearman

The highest strength is achieved in items measuring the frustration effects of aggression, neurosis, and over-compensation - which all exceed half of the linear correlation.

The last part of the LOGO test is divided into two parts. The first part presents the essence of three life stories and has two emphases: it is the bearer of perspective value and at the same time it encompasses the exemplification task for the second part. A life story / situation is presented on the basis of which the respondent chooses which woman is the happiest and which suffers the most based on their own insight. At this point, it is necessary to recall the logotherapeutic assumption that flexibility in finding and determining meaningful goals is crucial for residential safety.

Results of the first part:

\begin{tabular}{|c|c|c|}
\hline Answers & No. of answers & Answers in \% \\
\hline A & 88 & 44.0 \\
\hline C & 44 & 22.0 \\
\hline B & 68 & 34.0 \\
\hline
\end{tabular}

Table 11: Tabular results for $\log 032 \mathrm{~A}$

\begin{tabular}{|c|c|c|}
\hline Answers & No. of answers & Answers in \% \\
\hline B & 74 & 37.0 \\
\hline
\end{tabular}




\begin{tabular}{|l|l|l|}
\hline C & 75 & 37.5 \\
\hline A & 51 & 25.5 \\
\hline
\end{tabular}

Table 12: Tabular results for $\log 032 B$

\begin{tabular}{|c|c|c|}
\hline Evaluation of responses & $\begin{array}{c}\text { No. of an- } \\
\text { swers }\end{array}$ & Answers in \% \\
\hline 0 & 3 & 1.5 \\
\hline 1 & 22 & 11.0 \\
\hline 2 & 130 & 65.0 \\
\hline 3 & 45 & 22.5 \\
\hline
\end{tabular}

Table 13: Tabular results for $\log 033 A$

\begin{tabular}{|c|c|c|}
\hline Evaluation of responses & $\begin{array}{c}\text { No. of an- } \\
\text { swers }\end{array}$ & Answers in \% \\
\hline 0 & 1 & 0.5 \\
\hline 1 & 24 & 12.0 \\
\hline 2 & 143 & 71.5 \\
\hline 3 & 32 & 16.0 \\
\hline
\end{tabular}

Table 14: Tabular results for $\log 033 B$

In the third part of the LOGO test, we are also interested in the correlation power of individual items in accordance with the total result of this part:

\begin{tabular}{|c|c|}
\hline $\begin{array}{l}\text { Categorised items of the } \\
\text { third part of the LOGO test }\end{array}$ & $\begin{array}{c}\text { Spearman's correlation coef- } \\
\text { ficient Sum logo 3 }\end{array}$ \\
\hline $\operatorname{logo32A}$ & .771 \\
\hline $\log 032 \mathrm{~B}$ & .723 \\
\hline $\operatorname{logo33A}$ & .579 \\
\hline $\log 033 \mathrm{~B}$ & .527 \\
\hline
\end{tabular}

Table 15: Correlation calculation for the third part according to Spearman

Apart from the fact that the first section of the third part of the LOGO test shows a slightly greater linear correlation with the result, there are no statistically significant differences. At the same time, it also confirms the internal congruence of the third part of the LOGO test. 
As can be seen from the following graph, this is expected to be a normal distribution of results:

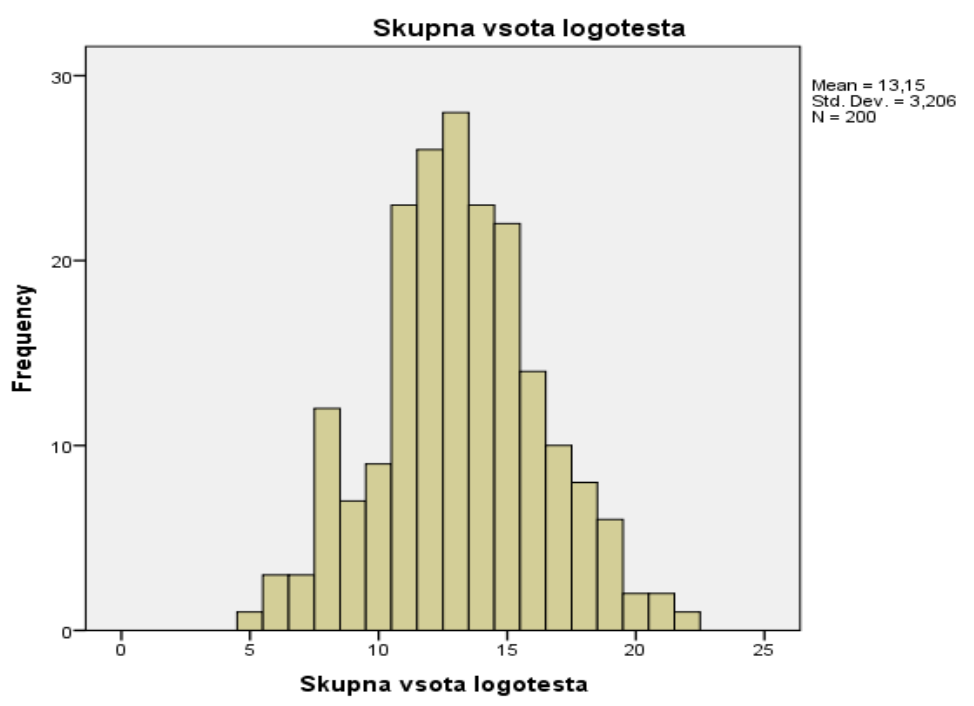

Image 1: Distribution of the total sum of the LOGO test

For greater clarity, we divided the results into two quantitative groups in accordance with the boundary of the crisis of meaning and added a percentage aspect:

\begin{tabular}{|c|c|c|c|c|c|c|c|c|}
\hline \multicolumn{9}{|c|}{ Age groups } \\
\hline Quarters & $16-29$ & & $30-39$ & & $40-49$ & & $50-59$ & \\
\hline $\mathbf{Q}_{1}$ & 9 & $22 \%$ & 10 & $15 \%$ & 2 & $3 \%$ & 3 & $11 \%$ \\
\hline $\mathrm{Q}_{2}+\mathrm{Q}_{3}$ & 29 & $71 \%$ & 47 & $71 \%$ & 38 & $58 \%$ & 14 & $52 \%$ \\
\hline$Q_{4}-\left(D_{9}+D_{10}\right)$ & 1 & $2 \%$ & 3 & $5 \%$ & 4 & $6 \%$ & 3 & $11 \%$ \\
\hline D 9 & 2 & $5 \%$ & 6 & $9 \%$ & 19 & $29 \%$ & 5 & $19 \%$ \\
\hline $\mathbf{D}_{10}$ & & & & & 3 & $5 \%$ & 2 & $7 \%$ \\
\hline
\end{tabular}

\begin{tabular}{|c|c|c|c|c|c|c|c|c|}
\hline Age groups \\
\hline Quarters & $\mathbf{1 6 - 2 9}$ & & $\mathbf{3 0 - 3 9}$ & & $\mathbf{4 0 - 4 9}$ & & $\mathbf{5 0 - 5 9}$ & \\
\hline “Normal” (Q1 + Q2 + Q3) & 38 & $93 \%$ & 57 & $86 \%$ & 40 & $61 \%$ & 17 & $\mathbf{6 3} \%$ \\
\hline Vacuum (Q4) & 3 & $7 \%$ & 9 & $14 \%$ & 26 & $39 \%$ & 10 & $37 \%$ \\
\hline
\end{tabular}

Table 16: Quarterly and decile classification of LOGO test results into two groups with added percentage aspect

(Due to the complexity of the measurement instrument and the results, we list only the key results that are directly related to our research question and hypotheses.)

\section{Discussion}

As can be seen from the summary results of the LOGO test (Table 16), which show a comprehensive evaluation, respondents in relation to the total population is 24 respondents (12\%) with good "fulfilment of inner meaning", 128 ISSN 1330-0067 respondents (64\%) with a central "fulfilment of inner meaning", 11 respondents $(5.5 \%)$ with poor "fulfilment of inner meaning", 32 respondents $(16 \%)$ with very poor "fulfilment of inner meaning" and 5 respondents $(2.5 \%)$ with the worst "fulfilment of inner meaning". The results of the survey thus show that as many as a quarter of respondents $(24 \%)$ feel existentially threatened or experience a crisis of meaning, frustration with life or are even in an existential vacuum that requires urgent therapeutic help. Specifically, this means that a quarter of all Coden: IORME7 
those tested are experiencing a crisis of meaning, which is very worrying given the symptoms and consequences of the existential vacuum. It indicates that a quarter of the entire population experiences serious and various levels of mental distress and experiences life at the existential level as empty and meaningless. They do not see a clearly articulated goal for their life, purpose and meaning. The consequences are manifested in unhealthy relationships, aggression (mental and / or physical), apathy, melancholy, feelings of inner emptiness, lack of self-initiative, addiction (chemical and / or non-chemical), anxiety, depression, despair, self-harm, eating disorders, etc. At this point, it should be emphasised that these are symptoms with a root cause on the spiritual level, as indicated by the research results. If the profession does not recognise and differentiate the origin and consequences, in all probability both the diagnosis and the treatment will be wrong.

The first part of the LOGO test covers nine logotherapeutic meaningful categories. Each item represents a specific "meaningful factor" of an individual's life (Table 2). The results show which content area (meaningful factor) individuals experience as the most important and which the least important. The individual marks the stated "meaningful factors" as their own, which consequently also means the evaluation of the "fulfilment of the inner meaning" as their own. The worst evaluated factors of meaning are: "Life hardship", "serving belief" and "main job" (Table 2). The meaningful factor of "life distress" (overcoming illness, selfpreservation, reconciliation) is at the very bottom (268), which means that in the event of illness, any mental distress or worries quickly sink into inner depression and despair. An individual does not find meaning and motivation to try to improve their current situation. From a logotherapeutic point of view, the third path of inner fulfilment with meaning is when an unchanging situation arises that causes suffering for a person in one way or another (pain, guilt, death - the tragic trinity of existence); the path of realising the values of their position. The manner in which the individual adjusts to the current situation in order to take an appropriate positive position is crucial. Suffering also ISSN 1330-0067 has its meaning if we perceive it as an integral part of life. In this existential perspective on understanding suffering, suffering is also a "task" in a way. The meaning of suffering is in the way a person endures it or how they suffer.

The second part of understanding the results of this paper is in the phenomenon of the modern taboos of disease, fragility, transience, death, suffering... The spirit of time dictates to people the values of beauty, health, power, authority, consumerism, success and individualism, so these contents of life, which are an integral part of reality and the life of each individual, are difficult to face, and so are denied, made taboo and perceived as intruders into a person's reality. All this is explicitly seen right in the result of this item.

"Service to belief" is the second worst evaluated (224) meaningful factor ("I believe in and am at the disposal of a religious or political task or a task in the service of progress") (Table 2). It is about the attitude and relation of the individual to society, to the world, to life, to their neighbours and to the superfluous. Surprisingly low results confirm the labels of modern man, which are immanent introspection, egocentrism, individualism, self-sufficiency, introversion and the inability to truly love. Modern man puts only himself at the centre of his life and he is most important to himself. He does not have a developed sense of responsibility towards society, for his fellow man, for solidarity and empathy, and for caring for others. He does not experience what is "addressed" by others, by the world and life. He does not experience his life "as a task" to which he is obliged and "called", or the need to respond. The rate of noo-dynamics, which is a measure of mental health, is at an alarmingly low level. From this, we can conclude that the spiritual capacity for self-transcendence has been stunted in some way. It is self-transcendence, which is an intuitive spiritual ability for man to transcend himself and devote himself to something other than himself, that plays a key role in the perception and realisation of life as a task directly related to our second hypothesis. It is in the power of self-transcendence that man achieves his own self-realisation, life satisfaction, inner fulfilment and meaning to the greatest extent.

Coden: IORME7 
The third least evaluated (94) meaningful factor is "main job" (education, study, work, profession - "I find real fulfilment in my professional work, which I am currently doing or designing") (Table 2). In terms of content, this factor is largely related to the previous one. At the forefront is the meaning of one's own existence through creative values, which belong to the first place within the framework of logotherapeutic value categories (logotherapeutic credo the second triad). The individual realises the meaning of his existence through his creation, in the broadest sense. The basic ability is again self-transcendence, which largely defines "life as a task". The basic questions that arise here are: Does my career or study path fulfil, satisfy and make me happy? Do I experience my career as a mission, as a task, or do I experience it as a burden? Do I do what I do because I want to do it and I feel confirmed and self-actualised in it, or do I do it because I have to do it? The results show that this is one of the most deficient meaningful factors.

At this point, it is worth mentioning that later research has shown that members of the normal population, who on average responded YES fewer than five times and left one box unanswered, should be classified as "noogenically endangered". The same goes for the mentally ill - four YES responses or fewer.

The second part of the LOGO test psychometrically evaluates the occurrence of existential frustration in terms of the existential vacuum / sense crisis. Frustration effects with the worst results are: aggression (144), regression (123) and overcompensation (115) (Table 6). The frustration effect of regression indicates a high level of existential crisis and a deep sense of missing out on life (missed opportunities and wrong decisions in the past), and displeasure with themselves and their past life, which is in direct relation to perceiving life as a task. The results of the over-compensation frustration effect show a medium and high level of existential crisis which is reflected in the feelings of inner emptiness and uselessness, and in a low level of self-esteem, self-respect, and self-confidence. This assumption also relates to the field of relationships, which is the most apparent indicator of a quality life. The frustration effect includes the relationship to oneself and the ISSN 1330-0067 relationship to others - honesty, sincerity, and authenticity. An individual who feels an inner void and perceives their life as meaningless, as a burden and not as a task, experiences practical difficulties in dealing with genuine relationships. By concealing the actual situation from themselves and others, they increase the inner void as this assumption also includes the individuals' awareness of what they should be or how their life should be compared to the actual situation. The worst evaluated frustration effect is aggression, which is actually an expression of helplessness and inner weakness. An individual puts himself in the role of a victim of life, society, the world, or other circumstances, and thus on an unconscious level does not accept responsibility for his past decisions, for his current state of life, for relationships and the quality of his life. It is easier to be a victim of circumstances than to take responsibility for your life and relationships. Life is not experienced as a task, as a kind of duty to which I respond responsibly, but as a burden and as something I am a victim of. The consequences are mostly manifested in aggressive behaviour towards oneself and / or towards others (on a mental and / or physical level).

The results of the third part of the LOGO test (Table 11 - Table 15) are used mainly in the psychotherapeutic process, and they confirm the results and consistency of the first two parts at the statistical level. Based on this part of the LOGO test, we see that a satisfactory level of experience of inner meaning and at the same time a satisfactory level of living security and the ability to be flexible in establishing and finding meaningful goals is achieved by only $12-13 \%$ of respondents, which is a worryingly low figure. $65-70 \%$ of respondents are somewhere in between, which represents a potential danger of slipping into an existential crisis and consequently into an existential vacuum. About $20 \%$ of respondents are already in an existential vacuum and urgently need logotherapeutic treatment. Statistical analysis confirms the claim that the central problems of modern man are aimlessness, inner emptiness and misperception of life.

From the logotherapeutic point of view, the purpose of human efforts cannot be happiness or comfort, as they are only a side product

Coden: IORME7 
or a product of orientation towards the benefits of living in a manner that is true to personal values. Genuine happiness is not attained directly (happiness paradox), in the sense of seeking happiness for its own sake. The same applies to pleasure - pleasure for its own sake. Happiness comes "by itself" as a consequence of attaining some goal, life orientation, meaningful decisions, etc. There is always a cause or a reason for true happiness or pleasure. We should mention positive psychology here, which is the modern orientation in psychology and psychotherapy. The sub-title of a book on positive psychology by a famous author, Ilona Boniwell /16/, says a lot: The Science of Happiness. It means that positive psychology perceives itself as the science of happiness. In contrast, Frankl's logotherapy could be termed a science of life or science of meaning. Frankl is not only a specialist in two fields, but also a person who survived four concentration camps. Freud's theory did not apply in the camp: "If we try to equally expose a number of different people to hunger, all individual differences will disappear due to the dominant need for food, and a unified expression of unsatisfied instinct will occur in their place" $/ \mathbf{1 7} /$. On the contrary, the differences between people increased. The key question or answer for solving this problem, as we have already mentioned, is in an anthropological orientation - a search for the answer to the question: What is a human? Is a human a being of power, a being of pleasure, or a being of happiness? In a speech that Frankl made in memory of deceased members of the Society of Doctors (who died between 1938 and 1945) in Vienna on 25th March 1949, he offered a different answer. He asked himself: "So, what is a human? We got to know him in a way as probably no generation before us; we met him in a concentration camp - in a camp where everything that was not essential was stripped away from people; where everything people were obsessed with, disappeared: money - power - fame - happiness - and where only what a human cannot 'have', but what he has to 'be', remained. What was left was a human burnt with pain and annealed from the suffering who melted himself into his essence, into humanness (das Menschliche)" /18/. This humanity, however, can only be ISSN 1330-0067 realised in the perspective of perceiving one's life as a task. Life asks me questions - and I answer those questions. Because I am free in my decisions, I am also responsible for my decisions.

Based on the results, both hypotheses can be confirmed. Hypothesis 1 is very strongly confirmed, because the crisis of meaning is not experienced by $20 \%$ of respondents but by as many as $24 \%$. Hypothesis 2 is also unequivocally confirmed because, based on the results obtained, the internal sequence and correlation between the non-perception and the non-realisation of life is clearly seen as tasks and results that summarise and segment the level of the existential crisis and existential vacuum. Through understanding and interpreting the results of the research into logotherapeutic meaningful categories (meaningful factors), frustrating effects and the third part of the LOGO-test, in which the ability to fulfil the life goal or the sense that unchanging circumstances make it impossible to fulfil it, we also arrived at the answer to the research question with which we wanted to determine the areas that have the greatest impact on the crisis of meaning.

\section{Conclusion}

The results of our research completely confirm logotherapeutic theoretical assumptions and the spirit of time or the fundamental problems of a modern human, which is an immanent orientation into oneself, an existential crisis, and an inner fragility and powerlessness.

A human, as a transpersonal and selftranscending being, always seeks, consciously or unconsciously, the measure of their actions, the meaning and ideal in something outside it, that overcomes it. They cannot find it with immanent logic and in being focused on themselves. With its anthropological orientation, methods, and interdisciplinary approach, logotherapy rescues humans from fatal egocentricity. It avoids the previous attempts of psychotherapy to reveal to the human "what is missing", but wants to help to reveal "what is there" /19/. This is the essence of surpassing oneself and perceiving life as "an task" in orientation to some assignment or person. The human transcends himself by engaging in Coden: IORME7 
something that is not himself. You could say that a human is found only when he is "lost". We live in a new age paradigm that places great emphasis on finding oneself and dealing with oneself. If the spirit of time drags the modern human towards the position of egocentricity, logotherapy strives to do the opposite. Lukas also sees in this the spiritual progress of humanity, which is an ever-increasing overcoming of egocentric "central obsession" /19/. Which at the same time means experiencing your life as "a task" on an existential level.

The results of the research give us many current guidelines and have an important useful value in the field of mental health, quality of life and the educational process. By recognising the weakest areas and the main causes of the crisis for almost the entire generation of dissatisfied, apathetic and melancholic adolescents, we obtained important information on where and how to start solving the crisis. At the same time, we also found which contents we have most overlooked in the educational process. Of course, we want satisfied children and adolescents who have a constructed identity, a healthy self-image and self-confidence, who will be satisfied and know what they want from life and what content they want to give to their lives, and who will look at their lives as something beautiful, as a challenge, as a task.

Notes

/1/ Kristovič S., (2014), Reševanje krize smisla sodobnega človeka : osnove logoterapije, Celje: Celjska Mohorjeva družba: Društvo Mohorjeva družba.

/2/ Frankl V. E., (1994), Volja do smisla, Celje: Mohorjeva družba, p.21

/3/ Frankl V. E., (1994), Zdravnik in duša, Celje: Mohorjeva družba, p.37

/4/ Frankl V. E., (1994), Volja do smisla, Celje: Mohorjeva družba, p.26

/5/ Frankl V. E., (1994), Zdravnik in duša, Celje: Mohorjeva družba, p.38

/6/ Kleindienst P., (2019), Zgodovinski temelji sodobne paradigme človekovega dostojanstva. Phainomena: glasilo Fenomenološkega društva v Ljubljani 28, št. 108/109, 259-282, p.263

/7/ Kleindienst P., (2017), Understanding the different dimensions of human dignity: analysis of the decision of the Constitutional
Court of the Republic of Slovenia on the "Tito street" case. Danube: law and economics review 8, št. 3, 117-147, p.126

/8/ Frankl V. E., (1994), Zdravnik in duša, Celje: Mohorjeva družba, p.39

19/ Frankl V. E., (1994), Volja do smisla, Celje: Mohorjeva družba, p.35

/10/ Frankl V. E., (1994), Zdravnik in duša, Celje: Mohorjeva družba, p.87

/11/ Frankl V. E., (1983), ... Trotzem hat das Leben einen Sinn: Argumente für einen tragischen Optimismus. Tiroler Landerstheater zu Innsbruck (6. juni 1983). Audiotext Kasettenproduktion. Zvočni posnetek predavanja.

/12/ Frankl V. E., (1994), Zdravnik in duša, Celje: Mohorjeva družba.

/13/ Frankl V. E., (2005), Človek pred vprašanjem o smislu, Ljubljana: Pasadena, p.188

114/ Frankl V. E., (1994), Zdravnik in duša, Celje: Mohorjeva družba, p.80

/15/ Lukas E., (1986), Test zur Messung von 'inner Sinnerfülung' und 'existentieller Frustration', Wien: Franz Deuticke Verlagsgesellschaft $\mathrm{mBH}$.

/16/ Boniwell I., (2012), Positive Psychology in a Nutshell: The Science of Happiness, Open univerity press: Milton Keynes.

/17/ Frankl V. E., (2005), Človek pred vprašanjem o smislu, Ljubljana: Pasadena, p.36-37

/18/ Op.cit., p.74

/19/ Lukas E., (2001), Tudi tvoje trpljenje ima smisel. Celje: Mohorjeva družba, p.194

/20/ Op.cit., p.199

Literature

1. Fabry J. B., (1988), Guideposts to meaning. Discovering What Really Matters, Oakland: New Harbinger Publications.

2. Fizzotti E., (2007), Il senso come terapia. Fondamenti teorico-clinici della logoterapia di Victor E. Frankl, Milano; FrancoAngeli.

3. Frankl V. E., (2016), Preslišani krik po smislu Psihoterapija in humanizem, Celje: Mohorjeva družba.

4. Frankl V. E., (2005), Man's Search for Ultimate Meaning. London: Random House Group.

5. Frankl V. E., (1985), Der unbewusste Gott, München: Kösel-Verlag.

6. Galimberti U., (2015), Miti našega časa, Ljubljana: Modrijan.

7. Holiday R., (2016), Ego is the Enemy: The Fight to Master Our Greatest Opponent, New York: Portfolio, Penguin. 
8. Kant I., (2003), Kritika čistoga uma, Beograd: Dereta.

9. Kristovič S., (2016), Med smislom in nesmislom trpljenja, Celje: Celjska Mohorjeva družba.

10. Lukas E., (2017), OSNOVE LOGOTERAPIJE Človeška podoba in metode, Celje: Celjska Mohorjeva družba; Društvo Mohorjeva družba.

11. Lukas E., (1993), Družina in smisel, Celje: Celjska Mohorjeva družba.
12. Lukas E., (1986), Meaning in Suffering: Comfort in Crisis Through logotherapy, Berkeley: Institute of Logotherapy Press.

13. Pattakos A., (2010), Prisoners of Our Thoughts Viktor Frankl's Principles for Discovering Meaning in Life and Work, San Francisco: Berret-Koehler Publishers.

14. Williams R., (1997), Navadna kultura. Izbrani spisi, Ljubljana: Studia Humanitatis. 